\section{A Decade of Success}

$J$ ocelyn Smith, David Mackett and Lindsay Bunce know their work with the Lake Superior First Nations Development Trust (LSFNDT) is making a difference for First Nation communities. Started in 1992, the not-for-profit organization delivers important economic, educational and resource development services in northern Ontario. With financial support from the FNFP and other funding programs, LSFNDT is involved in many projects, three of which are described below. For more information see www.lsfndt.org/.

Aboriginal Forest Fire Training and Employment Program: the provision of extra firefighting protection for the Ontario Government continues to be a model of success, according to evalua- tions conducted by the Ontario Ministry of Natural Resources. LSFNDT employs over 100 First Nation members during peak fire seasons.

Megwekob - Aboriginal Forestry in Boreal Northwest of Ontario: LSFNDT has built a strong presence on the Internet through the development of its Web site and the online distribution of the Megwekob (pronounced Meh-Kwab) newsletter. It provides an accessible and interactive forum for discussing issues of importance concerning Aboriginal forestry in the boreal forest region. The goals are to make forest sector issues accessible to communities so their participation is included, and to make information and online tools related to forest development resources increasingly accessible.

\title{
Une décennie de succés
}

$J$ ocelyn Smith, David Mackett et Lindsay Bunce savent que leur travail chez Lake Superior First Nations Development Trust (LSFNDT) marque une différence pour les collectivités des Premières Nations. Créé en 1992, l'organisme à but non lucratif assure d'importants services à l'économie, au secteur de l'éducation et du développement des ressources du Nord de l'Ontario. Avec le soutien financier du PFPN et d'autres programmes de financement, LSFNDT est engagé dans de nombreux projets dont nous en décrivons trois ci-dessous. Pour plus de renseignements, visitez www.lsfndt.org

Programme des Autochtones de formation et d'emploi en protection des forêts contre les incendies: La prestation d'une protection supplémentaire contre les feux de forêts pour le gouvernement de l'Ontario continue d'être un modèle de réussite, d'après les évalu- ations menées par le ministère des Richesses naturelles de l'Ontario. LSFNDT donne de l'emploi à plus de 100 membres des Premières Nations durant les saisons exposées aux risques d'incendie.

Megwekob - Foresterie autochtone dans le bouclier boréal du Nord-Ouest de l'Ontario: LSFNDT est très présent sur la Toile grâce à la création d'un site Web et la diffusion en ligne de son bulletin Megwekob (prononcez MehKwab). Megwekob Online ouvre un forum interactif d'échange de vues sur les questions qui intéressent la foresterie autochtone dans la région de la forêt boréale. Il se propose ainsi de rendre les principaux enjeux forestiers ainsi que les renseignements et les outils en ligne liés aux ressources du développement forestier de plus en plus accessibles aux collectivités pour qu'elles en soient parties prenantes.
Système d'information géographique (SIG) et gestion de l'information: LSFNDT a mis en service et entretient depuis 1993 un SIG que plusieurs collectivités des Premières Nations ontariennes utilisent pour recueillir des données qui reflètent la connaissance traditionnelle écologique. Ces partenariats, fondés sur la communication et la confiance, permettent la collection et l'intégration des valeurs autochtones ancestrales et contemporaines dans les plans d'aménagement des forêts et des parcs en vue de la promotion et(ou) de la protection de ces valeurs et de ces territoires. Les données trouvent de multiples applications, y compris la création d'une bibliothèque historique numérique, la résolution de conflits, l'aménagement du territoire et les initiatives de développement du tourisme. 


\section{Hope Translates into Big First Steps for Penelakut Forestry}

W hen Penelakut Tribe Band Manager Lisa Shaver looks at the forest, she sees more than just trees. Lisa sees a part of her people's heritage that could play an important role in her community's social and economic development.

The Penelakut Tribe is a Coast Salish community. Penelakut means "something buried." The Tribe is located on Kuper Island about $60 \mathrm{~km}$ north of Victoria, between Vancouver Island and the mainland of British Columbia. Thanks in part to $\$ 25,000$ provided by the First Nations Forestry Program (FNFP) in 2003, the Penelakut Tribe is creating economic opportunities from forestry while maintaining their traditional respect for the environment and its resources.

Lisa explains that the FNFP project enabled them to create a forest community development plan in partnership with Shelterwood Forest Management Ltd., a consulting company in Courtenay, British Columbia. About a halfdozen members already had forestry experience in logging and silviculture, but working with Shelterwood, the Penelakut Tribe mapped out a more detailed forestry development plan. Highlights of the plan include: using their existing portable sawmill as a value-added lumber operation, developing harvesting and silviculture prescriptions on reserve land, securing a woodlot harvesting licence, developing fire suppression capacity, providing basic forestry training, and exploring off-reserve forest tenure opportunities.

The forest management plan is being implemented successfully. Progress comes from being positive and open to new opportunities. Right now, the Tribe is concentrating on reforestation. The forest training program graduates are working on the reserve, although not all in forestry. The training has given some the confidence to explore other business ventures. Lisa is also feeling very positive about an alliance the Penelakut Tribe is building with merchants in Chemainus, British Columbia to market their arts and crafts, including products made out of wood.

For more information Lisa Shaver, Penelakut Tribe shaver@uniserve.com

\section{La nation Penelakut reprend espoir avec les premiers travaux de foresterie}

\begin{abstract}
orsque l'administratrice de la bande de Penelakut tourne son regard vers la forêt, Lisa Shaver ne voit pas uniquement des arbres. Elle contemple une parcelle du patrimoine de son peuple qui pourrait jouer un important rôle dans le développement social et économique de sa collectivité.

La bande de Penelakut est une tribu des Salish du littoral. Penelakut signifie " quelque chose d'enfoui ». La tribu réside sur l'île Kuper à une soixantaine de kilomètres au nord de Victoria, entre l'île de Vancouver et la ColombieBritannique continentale. Grâce en partie aux 25000 \$ affectés par le Programme de foresterie des Premières nations (PFPN) en 2003, la tribu de Penelakut Tribe crée des perspectives économiques liées aux richesses de la forêt tout en préservant le respect traditionnel de l'environnement et de ses ressources.
\end{abstract}

Lisa explique que le projet du PFPN a permis la création d'un plan de développement communautaire de la forêt en partenariat avec Shelterwood Forest Management Ltd., une société d'experts-conseils basée à Courtenay (C.-B.). Une demi-douzaine de membres de la bande avaient déjà une certaine expérience des opérations forestières et des notions de sylviculture mais, de concert avec Shelterwood, la tribu de Penelakut a pu élaborer un plan de développement forestier plus détaillé. Ses grandes lignes prévoient l'utilisation de la scierie mobile existante en tant qu'opération de sciage à valeur ajoutée, des prescriptions de récolte et de sylviculture sur les terres de la réserve, l'obtention d'un permis d'exploitation de lots forestiers, le développement de la capacité de suppression des incendies, une formation de base en foresterie et la prospection des occasions de mode de tenure forestière hors réserve.

Le plan de gestion forestière est appliqué avec succès. Les progrès enregistrés découlent d'une attitude positive devant les possibilités qui s'ouvrent. En ce moment même, la tribu se concentre sur le reboisement. Les diplômés du programme de formation sylvicole travaillent sur la réserve, même si tous ne sont pas engagés dans le secteur forestier. La formation leur a donné l'assurance et le désir d'explorer d'autres avenues commerciales. Lisa nourrit l'espoir que la tribu de Penelakut parviendra à nouer une alliance avec les commerçants de Chemainus (C.-B.) pour la mise en marché de leurs objets ouvrés et d'artisanat, y compris les articles en bois.

Pour plus amples renseignements Lisa Shaver, tribu de Penelakut. shaver@uniserve.com 


\section{A Demonstration Woodlot Dedicated to Traditional Values}

he Madawaska Maliseet First Nation, working in collaboration with the Université de Moncton, Nexfor Fraser Papers Inc., and the FNFP-Atlantic, is setting up a demonstration woodlot as part of an ecotourism complex along the Iroquois River near Edmundston, New Brunswick.

The site also features a trout hatchery and fish-out pond, nature trail, examples of stream enhancement strategies, a campground, an interpretive center with aquatic biological exhibits and a history of Aboriginal fisheries in New Brunswick, and a retail outlet selling band-produced wares such as smoked fish, maple syrup, fiddleheads and crafts. The ecotourism complex itself is a work in progress and slated to open in several years. With funding support from the FNFP-Atlantic, two forestry students from the Université de Moncton in Edmundston inventoried timber and flora on the 87.3 ha demonstration woodlot during the summer of 2004. An interpretive trail was constructed through the woodlot focusing on First Nation medicinal, food and

craft flora found throughout the area. With the assistance of band member

The Madawaska Maliseet First Nation, working with the Université de Moncton, Nexfor Fraser Papers Inc., and the FNFP-Atlantic, is setting up a demonstration woodlot along the Iroquois River.
D a $r$ r y 1 Nicholas, 48 medicinal plants along the trail have been identified, photographed and discussed in a trilingual (Maliseet, French, and English) booklet. Copies of the booklet are available at the interpretive centre.

\section{Site d'un boisé de démonstration respectueux des valeurs traditionnelles}

\begin{abstract}
a Première Nation Malécite de - Madawaska, en collaboration avec l'Université de Moncton, Nexfor Fraser Papers Inc. et le PFPN-Atlantique, procède à l'aménagement d'un boisé de demonstration dans le cadre d'un complexe d'écotourisme ouvert le long de la rivière

La Première Nation Malécite de Madawaska, avec I'Université de Moncton, Nexfor Fraser Papers Inc., et le PFPN-Atlantique, procède à l'aménagement d'un boisé de démonstration le long de la rivière Iroquois.
\end{abstract} Iroquois, à proximité d'Edmundston (Nouveau-Brunswick).

Sur le site se trouvent également une écloserie de truites et un étang de pêche-sur-place, un sentier d'interprétation de la nature, des exemples pra- tiques de stratégies d'amélioration des cours d'eau, un terrain de camping, un centre didactique comprenant des éléments d'exposition de biologie aqua- tique et retraçant l'histoire des pêches autochtones au Nouveau-Brunswick, et un magasin où sont détaillés les produits de la bande : poisson fumé, sirop d'érable, crosses de violon et produits d'artisanat. Le complexe destiné à l'écotourisme proprement dit est encore en chantier et son inauguration est prévue dans quelques années. Grâce au soutien financier du PFPN-Atlantique, deux étu- diants en foresterie de l'Université de Moncton à Edmundston ont réalisé un inventaire du bois et de la flore sur un boisé de démonstration de 87,3 ha durant l'été 2004. Un sentier d'interprétation de la nature a été tracé dans le boisé, illustrant notamment les plantes médicinales et comestibles et servant à la fabrication d'objets que la Première Nation trouvait sur les lieux mêmes. Avec l'aide du membre de la bande Darryl Nicholas, 48 plantes médicinales ont été identifiées le long du sentier, puis photographiées et décrites dans une brochure trilingue (en malécite, français et anglais). Des exemplaires de la brochure sont disponibles au centre d'interprétation.

\section{Forestry Careers and Employment Your Internet Gateway to Forestry and Forest Products}

The Forestry Careers and Employment Bulletin Board lists job openings in every branch of Canada's forest sector - in woodlands, in manufacturing, in sales, in research and education. If you are looking for a job, check out our current listings below. Bookmark this page as we are constantly posting new opportunities.

This is a service open only to Canadian citizens, landed immigrants in Canada, or to those would otherwise qualify to work in Canada.

www.canadian-forests.com/job.html 